\title{
The impact of humorous advertising on consumers' buying, word of mouth and recall
}

\author{
Ghada W. El-tazy \\ Arab Academy for Science, Technology and Maritime Transport, Egypt \\ Hesham O. Dinana \\ The American University in Cairo, Egypt
}

\section{Keywords}

Humor, Advertising, Recall, WOM, Attitude, Consumer

\begin{abstract}
This paper aims at investigating the effect of "humorous advertising" on the Egyptian viewer. It is studying the effect of humorous advertising (HA) on the consumer's buying behaviour, probability to purchase and actual sales, as mediated by the attitude; along with studying its effect on recall and Word of Mouth. The research depends on both qualitative and quantitative data. Qualitative data includes five interviews with advertising experts and two focus groups, one with youth and another with adults. Quantitative data were collected through a survey. The data revealed that using humour in ads affects positively and strongly consumer attitude which has positive strong effect on probability to purchase; yet the consumer attitude effect on actual purchase choice was direct weak. Humour in ads has positive strong effect on word of mouth; as well as on recall. The marketers can use the humorous execution to lead to branding. As well as the paper clarifies for advertising agencies that this appeal needs special care in its creation to lead to the intended result; otherwise, it could lead to the opposite result. This paper fulfils an identified need to know the best marketing objective that can be achieved through humorous advertising.
\end{abstract}

Corresponding author: Hesham Dinana

Email addresses for corresponding author: hdinana@aucegypt.edu

First submission received: 7 th June 2017

Revised submission received: 22nd July 2017

Accepted: 20 August 2017

\section{Background}

There are two types of ads, cognitive and emotional. Advertisers and marketers attempt to select the right type to achieve the campaign objective by getting a certain reaction out of the viewers, that can be characterized as "advertising stimulus effects" (Percy and Rossiter, 1992). Humor in ads is categorized as an emotional appeal. Although humorous ads cannot be purely categorized as emotional appeals because not all their types require emotional processing, some of them need cognitive processing as well (Spielmann, 2014).

Previous research resulted in finding a relation between perceived humor and affective factors, such as attitude towards the ad (Gelb \& Zinkhan, 1986). This research though is mainly about studying some cognitive factors, namely "recall and persuasion". However, the relation between persuasion, which is represented in that research as consumer's buying, and Humorous Ads (HA) is mediated by the attitude. Previously both ads and Word of Mouth (WOM) were considered as alternatives (Huang, Cai, Tsang \& Zhou, 2011), but now they seem more as complementary. Because advertisers and companies should focus on the types of ads that can promote positive WOM about the brand and products (Casielles et al., 2013), one of this paper objectives is to answer if Humorous Ads (HA) can promote positive WOM about the brand, along with studying the recall and persuasion as mentioned above.

\section{Humor}

A humorous Ad can be described shortly as a funny ad. The humor does not have a clear definition as it has many dimensions; Humorous Ads (HA) become successful when the audiences have positive responses for it (Fugate, 1998). 
There are different techniques of humorous ads, such as arousal- safety (A-S), incongruity resolution (IR) (Spielmann, 2014) and humorous disparagement (Hatzithomas et al., 2011; Brown et al., 2010; Alden et al., 2000). Arousal- safety (AS) comes from the relief theory (Brown et al., 2010); the situation can be funny after being sure that things are safe (Spielmann, 2014). Incongruity resolution (IR), as stated in two theories in psychology, is mostly a reflection of incongruity and incongruity resolution that causes laughter (Duncan, 1982). One theory demonstrates that incongruity alone is sufficient to create humor; the other one says that incongruity alone might make the audience confused, as they simply did not get the joke; therefore, its resolution is necessary to be humorous (Alden and Hoyer, 1993; Alden et al., 1993). Humorous disparagement (HD) as mentioned by Brown et al. (2010) is the disparagement humor that could be elicited by the desire to feel superior; as it is based on laughing at people in an attempt to feel you have control over them.

\section{Recall}

The exposure of the population to the advertising along with recall is the first sign to be effective for a media campaign (Dunlop et al., 2014). The memory network in our brains works through what is called "spreading activation" theory; that theory states that in our subliminal level certain nodes are activated when we are exposed to certain stimuli, this activation moves from nodes to other nodes through links (or associations) among them; the amount that moves the activation depends on the strength of the link; the nodes are the pieces of information, such as brands, product features and attributes... and so on; this network is called "the cognitive structure". The information of these nodes moves from subliminal level to conscious level when activation overrides specific threshold (Grunert, 1996). Though most of the recalling process or information is made in the subliminal level, called "automatic process", the conscious level, called "strategic process", interferes as well sometimes; for instance, if someone asks you certain question, you start consciously the activation process to recall the information. One of the things that enhance the subliminal processing is the context in which the advertisement is placed; because "perception of the context facilitates perception of the advertisement" if they are related to each other (Grunert, 1996). Moreover, the similar the ad's source and even non-source cues to its target, the better; because that closeness will cause better automatic activation in the memory (Brumbaugh, 2002). Dunlop et al. (2014) mentioned that recency, being exposed recently to the ads, causes more recall along with the idea in its launch phase, novelty, more than replicating it with other executions. In addition, the more frequent the target audience is exposed to the ad, the better their recall gets. The frequency can be measured through "commercial TV ratings data providing Gross Rating Points or GRPs".

Gelb \& Zinkhan (1986) debate that humor does not positively affect comprehension and "specifically, the ability to "play back" a message accurately", but also there was no significant difference if the ad was serious. There was other research suggesting that humor causes less comprehension because of distraction (Bergeron \& Vachon, 2008) that is changing the people's focus from the content to the context (Spielmann, 2014). However, there were some who concluded that humor causes better memorability and recall (Alden et al., 1993; Miller, 1996; Alden et al., 2000) along with the ad's attention (Tomkovick et al., 2001; Brown et al., 2010). Therefore, this paper is to examine which one of these contradicting results is the case in Egypt.

\section{Persuasion}

Persuasion is defined in the literature as the attitude and consumer's buying. Further, consumers' buying is represented as purchase intentions and actual choice (Gelb \& Zinkhan, 1986). The attitude can be defined as, the tendency to have favorable or unfavorable response to a certain ad exposure. It is mentioned in more than a study that attitude towards the ad is usually reflected on the brand and products, namely, if the attitude for the ad is favorable, that will be the case of its advertised product and brand as well as the purchase intentions (Tomkovick et al., 2001).

Probability to purchase or purchase intention can be defined as the desire to repurchase a product from the same provider. It includes several factors such as the probability that the person will actually repurchase, and the time expected to repurchase (Bergeron \& Vachon, 2008). The purchase intent is studied massively in both marketing and economics fields; in marketing, it helps predict the sales; in 
economics, it helps measure the confidence level of the economy (Bemmaor, 1995). In marketing, there are different factors that affect the intentions of purchase, such as store image, perceived value, pricing, discounts... and so on (Grewal, Krishnan, Baker \& Borin, N.D.).

Actual willingness to pay and purchase is defined as, the actual maximum payment an individual will pay to get the product (Barber et al., 2012). Bemmaor (1995) stated that the intent to purchase is not a precise predictor of the actual behavior (Barber et al., 2012) for many reasons; one of them is that the respondents of a survey that asks them about their intent to buy may actually change their intention after the survey time. In addition, one of the reasons could be lack of information at the time of the intention that is discovered at the actual buying time (e.g., actual price).

This research is studying the effect of humor on consumer's buying represented as both purchase intentions and actual choice. The attitude towards the ad is mediating the relation between HA and consumer's buying as Gelb \& Zinkhan (1986) found that there is a significant positive relation between the humorous ad (HA) and attitude; while the relation between HA and purchase intentions, and HA and actual choice were positive but not significant. Thus, this research assumes that attitude mediates the relation between humor and consumer's buying represented by two elements purchase intentions and actual choice. As Alden et al. (2000) stated that for a factor to be a mediator between other two factors, there are mainly four terms, three of them are about having direct relations on each other; that is each independent factor affects directly on a dependent one. The fourth is that the direct relation between two factors is affected when the third factor changes.

\section{Word- of-Mouth}

WOM is an abbreviation for "Word-of-Mouth"; that is telling others about the product of a certain supplier from a non-marketing source (Bergeron \& Vachon, 2008). As far as to the researcher's knowledge, Bergeron \& Vachon (2008) were the first to link humor and WOM in the financial advising field, as it depends on social networks that humor increases, they found that there is a very strong positive relation between them; namely, the better the advisors' skills of humor, the more the probability of their customers to engage in WOM (Söderberg, 2013). In advertising filed, according to Bussiere (2009), there was only one study that examined the impact of humorous ads on stimulating WOM and it was found that HA positively affects the willingness of the audience to WOM.

WOM importance is well known in business and marketing. It is seen as the most powerful tool (Lau and $\mathrm{Ng}$, 2001). It was proven that there is a direct positive relation between the WOM and sales. The sales increases if WOM is positive and decreases in the opposite case (Barreto, 2014). It was also proven that WOM is nine times more effective in changing people's attitude than advertising, seven times more effective than newspapers ads, that was the first study about WOM effect (Trusov, Bucklin \& Pauwels, 2008), four times than direct sales, three times than advertising in promoting purchases and twice than radio advertising over different researches and years since the 50's (Goyette et al., 2010). That importance and strong relation came because of many reasons one of them is that the teller of WOM is not a marketing source, so WOM is perceived as more credible (Casielles, álvarez \& Río-lanza, 2013; Spreng, Harrell \& Mackoy, 1995) than other marketing tools as the teller has no self-interest to give the recommendation (Lau and Ng, 2001; Bergeron \& Vachon, 2008).

The basic difference between traditional WOM and mass communication is that WOM is a face to face interaction, while mass communication has different media methods to transfer information; also WOM has more influence on consumers than mass communication; it easily transfers low cognition and effect into high; moreover, the face-to-face and interpersonal features facilitate access to information and make receivers judge its information heavily, which increases the actual choice probability; the receivers usually attempt to get information through WOM to reduce the perceived risk while they are making their decision to purchase (Lau and $\mathrm{Ng}, 2001$ ). WOM was found to be more effective than traditional marketing (O'Reilly \& Marx, 2011) in acquiring new customers online; as the signing up effect through WOM could last for three weeks, while through traditional marketing last from three to seven days; new members lead to WOM just as it leads to new members, these members do not necessarily have to be the targeted ones as the targeted ones could add others easily, which increases the acquisition possibility even if there were no traditional marketing activities; over and above "signup gains today may translate into higher signup gains tomorrow"; WOM was found also to be effective for longer time than traditional marketing which 
gives companies stronger reason to motivate people to WOM through their activities; WOM has better effect on brand choice than advertising or personal search. (Trusov et al., 2008)

Since WOM is important for companies, they attempt to know what could lead to positive and successful WOM to be able to benefit from it, and attempt to motivate people towards positive WOM (Barreto, 2014) through ads and sponsorships of different events, hoping that WOM about the events might generate WOM about their brands (Lau and $\mathrm{Ng}$, 2001). In other words, companies attempt to promote the WOM; that can be called WOMM (Word-of-Mouth Marketing) (O'Reilly \& Marx, 2011). There are campaigns now that are designed for that purpose, such as viral marketing, buzz marketing and referral programs; which is called "fertilized WOM" instead of waiting for the traditional WOM to happen (Trusov, Bucklin \& Pauwels, 2008; Barreto, 2014). Therefore, this paper is studying if HA is one of the traditional marketing ways that can promote positive WOM about the brand.

\section{Model \& Hypotheses}

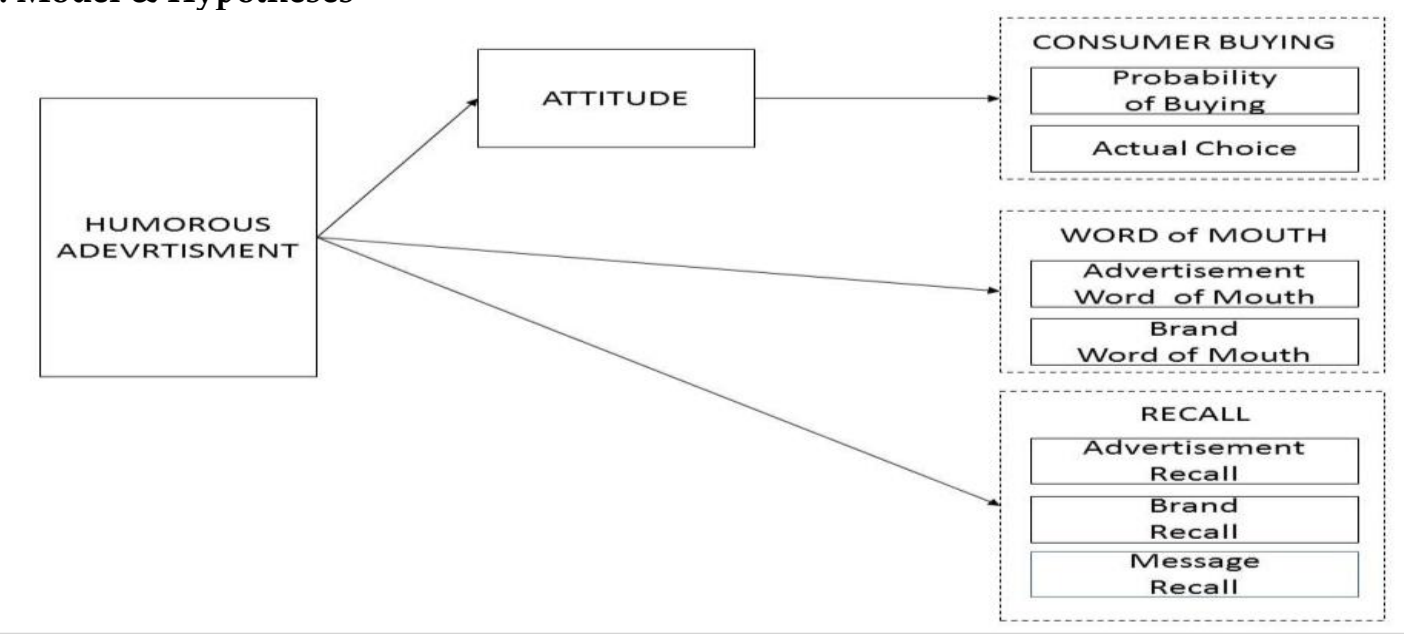

\subsection{The Model Variables}

Fig.1 The Research Model

A) Humorous Ads (Independent Variable) the model is mainly made to know the effects of humorous ads generally on the other variables in the Egyptian market.

B) Attitude (Mediating Variable) the attitude towards the ad in this paper is a mediating variable between HA in one hand and consumer's buying on the other.

C) Consumer's Buying (Dependent Variable) that variable includes two elements; the probability to purchase or the purchase intentions and actual choice. That is because actual choice is not necessarily the result for buying intentions in all situation.

D) Word-of-Mouth (Dependent Variable) studying if WOM can be promoted by using a humorous ad was not much researched. This research is of interest in that topic. Along with knowing if that WOM would be about the ad's humorous situation only or also the brand.

E) Recall (Dependent Variable) studying if using humor in ads may enhance the recall of the message and the brand, or only enhances the recall of the humorous situation, or does not help recall at all.

\subsection{Research Hypotheses}

Hypothesis 1: There is a positive relation between humorous ads and attitude towards them.

Hypothesis 2: There is a positive relation between attitude towards humorous ads and consumer's buying.

Hypothesis 3: There is a positive relation between humorous ads and Word-of-Mouth.

Hypothesis 4: There is a positive relation between humorous ads and recall. 


\section{Method \\ 2.1 Design overview}

This research is based on both qualitative data represented in focus groups and interviews, and quantitative data represented in survey. The qualitative data shall give insight as well as ensuring the results of the quantitative data as it "reveals the story behind the quantitative analytics" and enable businesses to make informed decisions.

\section{A) Focus Groups}

Two focus groups were conducted and recorded. One included 8 persons whose ages ranged from 14 to 21 representing teenagers. The other group included 6 persons whose ages ranged from 43 to 59 representing adults. Although the age in that paper is not used as moderating variable, the groups were divided in terms of the age just to enlighten this part. Both groups included males and females. The number of persons in both groups, 6 and 8, is particularly chosen in order to get better indepth discussion as well as controlling them at the same time. First, they were shown a recent ad of a network. Second, they were asked questions regarding every variable in the study that are clarified in the analysis (e.g., did you really buy the product that the ad was about?). The chosen ad for the focus group was because of its recency. They were asked about another ad without showing it for testing the recall.

\section{B) Interviews}

Five interviews were conducted with advertising agencies' experts. Three of them worked in humorous ads campaigns and two did not. They were interviewed face to face or through the telephone.

\section{C) Survey}

Though many past researches on such topics used lab experiment with control group, in this research a TV ad was demonstrated first then the respondents were asked the variables questions with no control group, which is also a method used in previous research (Spielmann, 2014). The questionnaire was 5-points Likert scale and cross-sectional. The questionnaire was distributed online and offline. The online distribution ensures the variety of the sample but the offline was used because it was quicker in getting the responses. The questions are validated as they were taken from previous researches that measure the same variables, but some wording changes existed to make the questions suitable for that research. The demographic variables do not have a moderating effect based on the background. The sources and questions will be demonstrated in Table-1 below. Also for the sake of validating the questions, a pilot survey was conducted before the distribution. The opinions of five advertising and marketing professors were taken along with the opinions of ordinary respondents. The total number of these surveys was 15.

The ad that was shown before answering was chosen carefully among the recent different humorous ads. Finally, the ad was not only chosen for its recency, but also because consumer's buying can be easily measured as its product does not cost much, only one pound. Moreover, there are no switching costs in buying its competing products. Accordingly, the income and switching costs will not moderate the relation between the attitude and the buying behavior.

\begin{tabular}{|c|c|c|}
\hline Variables & Sources & Contribution \\
\hline $\begin{array}{c}\text { Humorous Ads } \\
\text { (Independent Variable) }\end{array}$ & $\begin{array}{l}>\text { Alden, Hoyer \& } \\
\text { lee, } 1993 \\
\text { Alden \& Hoyer, } \\
1993 \\
>\text { Spielmann, } 2014\end{array}$ & $\begin{array}{l}\text { Do you believe humor was intended in } \\
\text { this ad? }\end{array}$ \\
\hline $\begin{array}{l}\text { Attitude (Mediating } \\
\text { Variable) }\end{array}$ & Spielmann, 2014 & $\begin{array}{l}\text { Do you like humorous ads in general? } \\
\text { - ad easily entertains me } \\
\text { Humorous ads put me in a good mood } \\
\text { I immediately had a nice feeling about } \\
\text { - ad } \\
\text { Humorous ads generally does not } \\
\text { make me happy } \\
\text { - ad is what I would consider a "feel- } \\
\text { good" ad } \\
\text { I can easily relate happy memories } \\
\text { with Humorous ads }\end{array}$ \\
\hline
\end{tabular}




\begin{tabular}{|c|c|c|}
\hline $\begin{array}{c}\text { Consumer's buying } \\
\text { (Dependent Variable) }\end{array}$ & $\begin{array}{l}\text { Akhter, 2010 } \\
\text { Bergeron \& } \\
\text { Vachon, } 2008 \\
\text { Tang, Luo \& Xiao, } \\
2011 \\
\text { GREWAL, } \\
\text { KRISHNAN, } \\
\text { BAKER \& BORIN, } \\
\text { N.D. } \\
\text { The researcher } \\
\text { validated by the } \\
\text { pilot survey }\end{array}$ & $\begin{array}{l}\text { Purchasing - is good } \\
\text { I expect to purchase (or repurchase) } \\
\text { products and/or services from the } \\
\text { brands of humorous ads in the future } \\
\text { Purchasing -is reasonable } \\
\text { Purchasing a brand of a humorous ad } \\
\text { is rewarding } \\
\text { The probability that I would consider } \\
\text { buying products and/or services from } \\
\text { the brands of such ads is low } \\
\text { I am likely to purchase "-" within a } \\
\text { month } \\
>\text { Were you a regular buyer for "-_" } \\
\text { before the ad? } \\
>\text { After the ad did you buy "-_"? }\end{array}$ \\
\hline $\begin{array}{c}\text { Word-of-Mouth } \\
\text { (Dependent Variable) }\end{array}$ & $\begin{array}{l}\text { Bergeron \& } \\
\text { Vachon, 2008 } \\
\text { Goyette, Ricard, } \\
\text { Bergeron \& } \\
\text { Marticotte, } 2010\end{array}$ & $\begin{array}{l}\text { I spoke of - ad much more frequently } \\
\text { than other ads } \\
\text { I spoke of - ad to many individuals } \\
\text { favorably } \\
\text { I mostly say positive things to others } \\
\text { about humorous ads } \\
>\text { I mostly say negative things to others } \\
\text { about humorous ads } \\
>\text { I spoke of - much more frequently } \\
\text { than its competitors } \\
>\text { I recommended-for others } \\
>\text { I speak about the good sides of - } \\
>\text { I strongly recommend people buy } \\
\text { products from the brands of humorous } \\
\text { ads } \\
>\text { I have spoken badly of the brands of } \\
\text { humorous ads to others } \\
>\text { I discuss the variety of products offered } \\
\text { by the brands of humorous ads }\end{array}$ \\
\hline $\begin{array}{l}\text { Recall (Dependent } \\
\text { Variable) }\end{array}$ & $\begin{array}{l}\text { Malik \& Sudhakar, } \\
2014 \\
\text { Cline \& Kellaris, } \\
2007\end{array}$ & $\begin{array}{l}\text { The humorous ad made me recognize- } \\
\text { - among competing brands } \\
\text { Humorous ads helps me to recall its } \\
\text { brand before shopping } \\
\text { Is there a name of brand that only } \\
\text { comes to your mind associated with a } \\
\text { humorous ad when you make } \\
\text { a purchase decision? } \\
\text { If yes please mention the brand name } \\
\text { What did the commercial say? } \\
\text { Please, do not get back to - ad when } \\
\text { answering the following questions } \\
\text { What major claims did the ad } \\
\text { make? Please list as many as } \\
\text { you can remember } \\
\text { What other details about the ad } \\
\text { do you recall? }\end{array}$ \\
\hline
\end{tabular}

\subsection{Sampling Methods}

Table-1 Info about the survey questions

A sample of 200 received the questionnaire, after removing all questionnaires that were incomplete, the sample becomes 169. The sampling technique used was convenience that is a nonprobability method.

\section{Analysis}

\subsection{Qualitative Data Analysis}

\subsubsection{Focus Groups}

\section{A. the Teenagers and Youth Group:}

The results of that group indicated that not all humorous ads create positive attitude. If the idea was bad or was not represented well, it actually could create the opposite attitude among young people. The ad or the humorous situation is what is mostly recalled, then the message, then the brand. The humor did not seem to overcome the message for that group as they knew what the watched ad was about except for two. Though they recalled humorous ads they liked, which means they had positive attitude towards them, they did not buy just because of that attitude except only one person who actually did. It also did not necessarily motivate the intentions just because of the positive attitude. In addition, some mentioned 
that even any other type of ads would not motivate them. The word-of-mouth would not be made by the group, but they did not like the humor in the watched ad and thought that it was quite silly.

\section{B. The Adults Group:}

Again, like the younger group, if the idea is not good even if it meant to be funny, it actually creates negative attitude. The attitude here actually had an effect on both probability to purchase and actual sales unlike the younger group. Word-of-mouth seems to be made, putting into consideration that this group was asked for the WOM about the ad they watched and generally too, unlike the first group that was asked about the watched ad only. They would talk about the ad, but they said they would talk about the brand if they are interested in the product. Recalling a humorous ad is very strong as they remembered old ads, but could be related to the age somehow because the younger group remembered recent ads, but adults remembered the ads of their young days, so maybe humor gets more attention and effect at young ages. Moreover, unlike the other group, the humor seemed to overcome the message for the watched ad except for two.

\subsubsection{Interviews}

All of them said that the type of the ad is determined by the clients in their brief. Some said they can suggest that type only if the clients did not determine one and are not sure which type is the best for their product. Two out of those who worked in humorous campaigns mentioned the target audience is another factor for determining whether humor should be used or not. They said they are usually not involved in the results of the ad in terms of sales, yet there are some case studies that talk about an increase happened in sales after a humorous campaign. There is one who said when it comes to humor, things could be quite tricky, that is the ad could be very reputable, but the sales are not necessarily affected by that success. There is one of those who worked in a humorous campaign said that the sales of the product increased. Also, all of them believe that humor induces word-of-mouth. Some of them believe that the WOM could be for the ad itself not the brand, especially if the brand is not mentioned a lot during the ad. They all agreed that good humor creates surly good attitude. Yet, not all ads succeed in delivering good humor, which causes negative attitude for the ad that is perceived as silly or even provoking.

\subsection{Quantitative Data Analysis}

A "Chi Square" independent test is computed first in order to know if the variables of the paper are dependent on each other, namely they have a significant relation, or not. Then, if the variables are dependent, a "contingency coefficient", the suitable correlation measure because the data are interval, is computed to know if the relation between them is strong or weak and if it is a direct or indirect relation. The following Table-2 will summarize the acceptance of the hypotheses, along with the type of the relation:

\begin{tabular}{|r|l|c|l|l|l|}
\hline No. & Hypotheses & \multicolumn{2}{c|}{ P-value } & \multicolumn{2}{c|}{ Relation } \\
\hline 1 & $\begin{array}{l}\text { There is a relation between } \\
\text { humorous ads and attitude towards } \\
\text { them }\end{array}$ & 0.000 & accepted & 0.707 & $\begin{array}{l}\text { Direct } \\
\text { strong }\end{array}$ \\
\hline 2 & $\begin{array}{l}\text { There is a relation between } \\
\text { attitude towwards humorous ads and } \\
\text { consumer's buying }\end{array}$ & $\begin{array}{c}\text { Probability } \\
0.000\end{array}$ & accepted & 0.754 & $\begin{array}{l}\text { Direct } \\
\text { strong }\end{array}$ \\
\cline { 3 - 6 } & $\begin{array}{l}\text { Actual } \\
\text { choice } \\
0.006\end{array}$ & accepted & 0.299 & $\begin{array}{l}\text { Direct } \\
\text { weak }\end{array}$ \\
\hline 3 & $\begin{array}{l}\text { There is a relation between } \\
\text { humorous ads and word-of-Mouth } \\
\text { about the ads and brands }\end{array}$ & 0.000 & accepted & 0.707 & $\begin{array}{l}\text { Direct } \\
\text { strong }\end{array}$ \\
\hline 4 & $\begin{array}{l}\text { There is a relation between } \\
\text { humorous ads and recall of the } \\
\text { brand, ad and message }\end{array}$ & 0.000 & accepted & 0.707 & $\begin{array}{l}\text { Direct } \\
\text { strong }\end{array}$ \\
\hline
\end{tabular}

Table-2 Summary of the relations

Most of the respondents were females, as they represent approximately $64 \%$, and most of them were youth that ranged from 20 to 35; as they represent approximately $34 \%$ and least were old that start from age 60 and above; as they represent approximately $1 \%$, the rest of them were either less than 20 or ranged from 36 to 59. Men represented approximately $36 \%$ who ranged mostly from 20 to 35 as well; as they represent 
approximately $26 \%$ and no men in the participated sample were 60 years old or above, the least percentage in men were the adults who ranged from 35 to 59; as they represent approximately $1 \%$, the rest of them were less than 20 .

\section{Discussions and conclusions}

The quantitative data indicated that there is indeed a relation between humorous ads and attitude. The relation is direct which means the more the humor in the ad, the better is the attitude, namely humor leads to positive attitude. This relation is strong which supports what the experts mentioned in the interviews that humor leads to positive attitude. Yet, they also made a clear warning that humor should be well applied; otherwise the viewers may perceive it as silly or provoking, like the ad watched in the focus groups where humor was intended but the idea was provoking and not well executed.

There is also a significant relation between attitude and probability to purchase in Egypt. That relation is direct which means positive attitude leads to positive probability to purchase, namely increase the probability. That relation is strong as well which is supported by the older focus group; the young group mentioned that loving a humorous ad "positive attitude" will not increase their probability to purchase but that applies to loving any other type of ads too.

Actual sales and attitude relation in Egypt is significant and direct as well, but weak. That is explained by the focus groups as most of them clearly stated that loving ads is not enough to actually buy a product; even though the older group mentioned it may increase their intentions, it is quite different when it comes to paying actual money. Moreover, this result is supported by the experts in the interviews who mentioned that a humorous successful loved campaign does not always lead to sales increase.

Another variable studied was the word-of-mouth. The research explored if there is a relation between humorous ads and WOM in Egypt dividing it into two separate parts; word-of-mouth about the ad itself and word-of-mouth about the brand of the ad.

Both relations are direct and strong. That means; the better the humor, the more the viewers are induced to talk about both the ad and the brand. That is supported by both the experts and the older focus group; most of the experts, mentioned that the viewers talk about the brand as well as the ad especially if it was mentioned more than once in the ad. That was supported by the older focus group who mentioned that they talk about the brand if they were interested in its products as well as the ad; the younger group about one ad which they perceived as silly rather than humorous, so their negative answers could be because of that.

The last variable the research studied with humorous ads is the recall. Recall in that research was divided into three parts, recalling the brand, the ad and the message. The quantitative data result is the same for the three divisions; there is a significant strong direct relation between the humorous ads and the recall in Egypt. Namely, the better the humour, the higher is the recall. That is supported by the focus groups, as they all in both groups were able to remember humorous ads. Yet, the adults group, all but one, recalled old ads not recent, taking into consideration that most of the researcher's sample was young, maybe the recall of ads, message and brands are strong at younger ages than older. Specially, after taking care that the humor in the watched ad at the young group did not overcome the ad's content, unlike what happened with the adults group. Therefore, maybe if the sample was mostly consisted of old people, the research may have a different result. Moreover, usually the brand was remembered well if it was mentioned in the ad more than once.

This research paper is beneficial for marketing and advertising professionals. The recommendations of the researcher to the marketers are mainly based on the "advertising stimulus effects" mentioned above. Based on the results they can clearly use the humorous execution in order to lead to many responses:

- They should use it when their objective is to create favorable attitude towards the brand over time, using this type of ads may cause positive classical conditioning with the brand.

- The results strongly show that "a good joke leads to a good talk". In other words, marketers can use HA to generate positive Word-of-Mouth.

- The strong positive recall caused by that appeal gives it a special importance because the target will not just recall the ad but also the brand and even the message that means that humor is associated with information processing especially if their target market consisted of young people. Therefore, marketers should use it for grabbing the attention, awareness and branding. 
- The results indicate also that this type of ads might not be the best to use if the objective is to increase sales in a short period. In fact, the young focus group did mention that neither this type of ads nor any other type of ads would lead them to purchase. Therefore, maybe marketers should use other promotional tools if their objective is making sales in a short period like sales promotion.

Recommendations that could be directed to advertising agencies are:

- The most important thing they should care for when they try to create a humorous situation is to understand the target very well because it is clear from the focus groups that the ad may not be funny although humor is intended. The problem of doing humorous ads that are not perceived as funny by the target market is that it creates a negative attitude and is perceived as provoking. The script and character used are very important as well. In short, this appeal needs special care in its creation to lead to the intended result not the opposite.

- Moreover, they must ensure that the brand is mentioned more than once throughout the ad in order to grab attention and achieve good recall.

\section{Research limitations and direction for further research}

One of the limitations in this research is that the constructs which are examined in the research are only those mentioned in the model; therefore, a future research may include other constructs, such as the product type and prior brand evaluations. Another limitation is that the researcher could not make a situation in which the respondents have to choose among different products; therefore, the measurement used in the research is considered as just an indication for the relation between the attitude and actual purchase. A future research could have better age and gender distribution; as most of that sample was young and women, it may even use them as moderating variables in order to know if there is a significant difference for that conclusion between both genders and among different age stages. The young focus group mentioned that their positive attitude caused by HA will not lead them to purchase but that is the case with the other types of ads as well, so a future research may compare the effect of the attitude created by HA on consumer's buying with the other types of ads.

\section{References}

Bemmaor, A. (1995). Predicting Behavior From Intention-to-Buy Measures: The Parametric Case. Journal of Marketing Research, Vol. XXXIl, pp. 176-191

Brumbaugh, A. (2002). Source and Nonsource Cues in Advertising and Their Effects on the Activation of Cuiturai and Subcuiturai Knowledge on the Route to Persuasion. JOURNAL OF CONSUMER RESEARCH, Vol. 29, pp. 258- 269

Malik, A. and Sudhakar, B. (2014). Instrument for Brand Positioning and Sports Celebrity Endorsement in Measuring Purchase Intention of Consumers. International Journal of Education \& Management, 4(4), pp. 263-270

Barreto, A. (2014). The word-of-mouth phenomenon in the social media era. International Journal of Market Research, 56 (5), pp. 631- 654

Gelb, B. and Zinkhan, G. (1986). Humor and Advertising Effectiveness after Repeated Exposures to a Radio Commercial. JOURNAL OF ADVERTISING, Vol. 15, No. 2, pp. 15- 34

Tomkovick, C., Yelkur, R. and Christians, L. (2001). The USA's biggest marketing event keeps getting bigger: an in-depth look at Super Bowl advertising in the 1990s. JOURNAL OF MARKETING COMMUNICATIONS, 7, pp. 89-108

Bussiere, D. (2009). The Effects of Humor on the Processing of Word-of-Mouth. Advances in Consumer Research, Volume 36, pp. 399- 404

Alden, D. and Hoyer, W. (1993). An Examination of Cognitive Factors Related to Humorousness in Television Advertising. Journal of Advertising, Volume XXII, Number 2, pp. 29- 37

Alden, D., Hoyer, W. and Lee, C. (1993). Identifying Global and Culture Specific Dimensions of Humor in Advertising: A Multinational Analysis. Journal of Marketing, Vol. 57, pp. 64-75

Fugate, D. (1998). The advertising of services: what is an appropriate role for humor? Journal of Services Marketing, Vol. 12 Iss 6 pp. 453 - 472

Grewal, D., Krishnan, R., Baker, J.and Borin, N.(N.D.). The Effect of Store Name, Brand Name and Price Discounts on Consumers' Evaluations and Purchase In1tentions. 
Alden, D., Mukherjee, A. and Hoyer, W. (2000). The Effects of Incongruity, Surprise and Positive Moderators on Perceived Humor in Television Advertising. Journal of Advertising, Volume XXIX, Number 2, pp. 115

Lau, G. and Ng, S. (2001). Individual and situational factors influencing negative - word - of - mouth behavior. Canadian Journal of Administrative Sciences, 18 (3), pp. 163- 178

Söderberg, I. (2013). "Relationships between advisor characteristics and consumer perceptions", International Journal of Bank Marketing, Vol. 31 Iss 3 pp. 147 - 166

Isabelle Goyette, Line Ricard, Jasmin Bergeron and François Marticotte, 2010, E-WOM Scale: Word-of-Mouth Measurement Scale for e-Services Context. Canadian Journal of Administrative Sciences, 27, pp. 5-23

Miller, J. (1996). "Humor - an empowerment tool for the 1990s", Empowerment in Organizations, Vol. 4 Iss 2 pp. 16- 21

Bergeron, J. and Vachon, M. (2008). "The effects of humour usage by financial advisors in sales encounters", International Journal of Bank Marketing, Vol. 26 Iss 6, pp. 376 - 398

O'Reilly, K. and Marx, S. (2011),"How young, technical consumers assess online WOM credibility", Qualitative Market Research: An International Journal, Vol. 14 Iss 4 pp. 330 - 359

Grunert, k. (1996). Automatic and Strategic Processes in Advertising Effects. Journal of Marketing, Vol. 60, pp. 88- 101

Percy, L. and Rossiter, J. (1992). Advertising Stimulus Effects: A Review. Journal of Current Issues and Research in Advertising, Volume 14, Number 1, pp. 75- 90

Hatzithomas, L., Zotos, Y. and Boutsouki, C. (2011). "Humor and cultural values in print advertising: a crosscultural study", International Marketing Review, Vol. 28 Iss 1 pp. 57 - 80

Trusov, M., Bucklin, R. and Pauwels, K. (2008). Effects of Word-of-Mouth Versus Traditional Marketing: Finding from an Internet Social Networking Site. Pp. 3- 48

Minxue Huang Fengyan Cai Alex S.L. Tsang Nan Zhou, (2011),"Making your online voice loud: the critical role of WOM information", European Journal of Marketing, Vol. 45 Iss 7/8 pp. 1277 -1297

Brown, M., Bhadury, R. and Pope, N. (2010). The Impact of Comedic Violence on Viral Advertising Effectiveness. Journal of Advertising, vol. 39, no. 1, pp. 49-65

Spielmann, N. (2014)."How funny was that? Uncovering humor mechanisms", European Journal of Marketing, Vol. 48 Iss 9/10 pp. $1892-1910$

Barber, N., Kuo, P., Bishop, M., Jr, R. (2012)."Measuring psychographics to assess purchase intention and willingness to pay", Journal of Consumer Marketing, Vol. 29 Iss 4 pp. 280292

Spreng, R., Harrell, G. and Mackoy, R., (1995)."Service recovery: Impact on satisfaction and intentions", Journal of Services Marketing, Vol. 9 Iss 1 pp. 15 - 23

Casielles, R., Álvarez, L., and Río-Lanza, A. (2013). The Word-of-Mouth Dynamic: How Positive (and Negative) WOM Drives Purchase Probability an Analysis of Interpersonal and Non-Interpersonal Factors. JOURNAL OF ADVERTISING RESEARCH, pp. 43- 60

Dunlop, S., Perez, D., and Cotter, T. (2014). The natural history of antismoking advertising recall: the influence of broadcasting parameters, emotional intensity and executional features. Top Control 2014, 23, pp. 215222

Duncan, W. (1982). Humor in Management: Prospects for Administrative Practice and Research. Academy of Management Review, Vol. 7, No. 1, pp. 136-142 